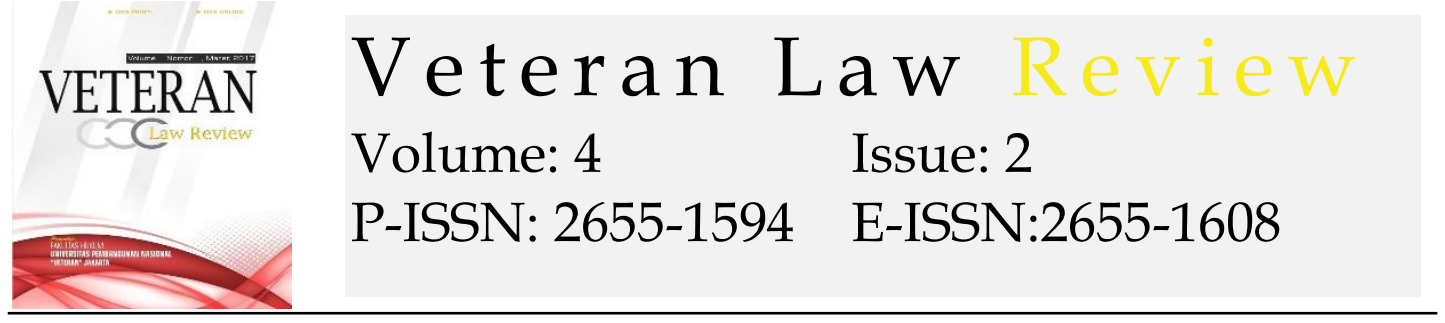

\title{
Legal Certainty on The Implementation of Electronic Registration of Liability Rights Performed by The Office of The Land Act Maker (Study at the Office of the Land Act Maker Deli Serdang)
}

\author{
Dicky Kurniawan Nasution ${ }^{1}$ Ahmad Fauzi ${ }^{2}$ Ruslan $^{3}$
}

${ }^{1}$ Faculty of Law, University Muhammadiyah of North Sumatera, Email: dickykurniawan@gmail.com ${ }^{2}$ Faculty of Law, University Muhammadiyah of North Sumatera, Email: ahmadfauzi@gmail.com ${ }^{3}$ Faculty of Law, University Muhammadiyah of North Sumatera, Email: ruslan@gmail.com

\begin{tabular}{|c|c|}
\hline E INFO & ABSTRACT \\
\hline $\begin{array}{l}\text { Keywords: } \\
\text { Legal certainty, HT-EL } \\
\text { registration, PPAT } \\
\text { How to cite: } \\
\text { Kurniawan, Dicky Et., } \\
\text { Al.. (2021) Legal } \\
\text { Certainty on The } \\
\text { Implementation of } \\
\text { Electronic Registration } \\
\text { of Liability Rights } \\
\text { Performed by The Office } \\
\text { of The Land Act Maker } \\
\text { (Study at the Office of } \\
\text { the Land Act Maker Deli } \\
\text { Serdang. Veteran Law } \\
\text { Review. } 4(2) .120 \text { - } 129 . \\
\text { Received: 2021-03-09 } \\
\text { Revised: 2021-09-22 } \\
\text { Accepted: 2021-10-22 }\end{array}$ & $\begin{array}{l}\text { Problem of legal certsinty on registration of liability rights performed } \\
\text { by the office of the land act maker because there is a regulation from } \\
\text { the Minister of Agrarian Affairs and Spatial Planning / Head of the } \\
\text { National Land Agency of the Republic of Indonesia has issued } \\
\text { Ministerial Regulation Number } 5 \text { of } 2020 \text { concerning Electronically } \\
\text { Integrated Mortgage Services. This research uses normative legal } \\
\text { research, which includes research on legal principles, research on } \\
\text { legal systematics, research on the level of legal synchronization, } \\
\text { research on legal history and comparative legal research. In this } \\
\text { study, the approach used is a statute approach, namely an approach } \\
\text { using legislation and regulations. The results of the discussion in } \\
\text { which the electronic mortgage registration process is based on the } \\
\text { provisions of Article } 9 \text { of the Regulation of the Minister of Agrarian } \\
\text { and Spatial Planning / National Land Agency (ATR / BPN) Number } \\
5 \text { of 2020, explains a creditor in applying for mortgage services } \\
\text { through the HT-el system provided by Ministry of Agrarian Affairs } \\
\text { and Spatial Planning / National Land Agency (ATR / BPN). In the } \\
\text { event that the application for HT-e services is in the form of a } \\
\text { Mortgage registration or a transfer of Mortgage Rights, the PPAT } \\
\text { must submit the required documents. Furthermore, in the event that } \\
\text { the application for HT-el Services is in the form of a change in the } \\
\text { name of the creditor, the abolition of the Mortgage Right, or } \\
\text { correction of data, the required documents shall be submitted by the } \\
\text { creditor. Furthermore, the requirements for application for HT-el } \\
\text { Services are in accordance with the provisions of laws and } \\
\text { regulations and are submitted in the form of an Electronic } \\
\text { Document. The obstacles for PPAT in registering HT-el, include } \\
\text { negligence, server interference, creditors not yet registered and not } \\
\text { validated in the Electronic HT service system. }\end{array}$ \\
\hline
\end{tabular}




\section{Introduction}

According to the provisions of Article 1 item 1 of Law Number 4 of 1996 on the Rights of Dependents which is meant by the rights of dependents are: "The rights of dependents on land and objects related to land, hereinafter referred to as the rights of dependents are rights of security imposed on rights to land as referred to in Law Number 5 of 1960 on the Basic Regulations of Agrarian Principles, with or without the following other objects that are one union with the land, for the repayment of certain debts, which give priority to creditors against other creditors".

Liability is defined as goods that are used as collateral. ${ }^{1}$ Security rights are security rights over land to pay off certain debts, which give priority to certain creditors over other creditors. The term "dependents" is a term used and related to insurance. In the world of insurance in Indonesia, the term "insured" is used as a synonym for "insurance". Accordingly, the term "insurer" which means an insurer or insurance company appears and the term "insured" means the party who is insured or insured. In connection with the use of the term "Mortgage Rights" in the LoGA and in the UUHT (Mortgage Rights Law), the insurance world has "challenged" the use of the term, as a special term for their world, other than the insurers. Because if, not the word "dependents" has two meanings, namely "guarantee (on land) and" insurance ".2

Mortgage is the control of land rights, containing the authority for creditors to do something about the land which is used as collateral. But not to be physically controlled and used, but to sell it if the debtor fails to promise and takes from the result all or part of the payment in full of the debtor's debt to him. ${ }^{3}$

Mortgage rights are defined as goods that are used as collateral. Meanwhile, the guarantee itself means that the loan is guaranteed. In the general explanation of Law Number 4 Year 1996 point 6 it is stated that "Mortgage Rights regulated in this Law are basically Mortgage Rights which are imposed on land rights. However, in reality there are often objects in the form of buildings, plants and works of art which are permanently an integral part of the land which is used as collateral. ${ }^{4}$

The Minister of Agrarian Affairs and Spatial Planning / Head of the National Land Agency of the Republic of Indonesia has issued Ministerial Regulation Number 5 of 2020 concerning Electronically Integrated Mortgage Services. This is a new breakthrough by taking advantage of developments in information technology to facilitate services to the public.

1 Salim HS. (2017). Perkembangan Hukum Jaminan di Indonesia. (pp. 95). Jakarta: Raja Grafindo Persada.

2 Rachmadi Usman. (2018). Hukum Jaminan Keperdataan (pp. 331). Jakarta: Sinar Grafika.

3 Budi Harsono. (2016). Hukum Agraria Indonesia: Sejarah Pembentukan Undang-UndangPokok Agraria, Isi, dan Pelaksanaannya (pp. 24). Djambatan.

4 AP. Parlindungan. (2011). Komentar Undang-Undang Tentang Hak Tanggungan atas Tanah Beserta Benda-benda yang berkaitan dengan Tanah.(pp. 14). Jakarta: Mandar Maju. 
This provision differs from the implementation of the registration of mortgage rights that has been running so far, which still allows the owner of immovable property (certificate) to be the guarantor for debtor's debt by making the certificate encumbered with the mortgage of the debtor's debt. This is generally applied by making a power of attorney to impose mortgage rights (SKMHT) drawn up in a notary, which outlines the power of attorney by the certificate owner to the creditor as collateral for credit by someone else. Although in practice not all financial institutions are willing to implement it, because of the risk of lawsuits from the certificate owner for the execution of mortgage rights.

However, the issuance of this Ministerial Regulation is an attempt by the government to facilitate the community. This HT-el Ministerial Regulation regulates that the registration of mortgage rights can be carried out by individuals or financial institutions (legal entities). If previously the registration of the right of responsibility was mostly carried out by Land Deed Making Officials (PPAT), then in this Ministerial Regulation regarding HT-el, creditors who have been verified can register HT online.

The form of mortgage certificate is also different from the usual one. Previously, it was in the form of a book which is almost similar to a certificate, then the HT-e certificate is in the form of a print-out sheet with an electronic signature and a QRcode (barcode) to prove its authenticity, which the creditor can print himself. The time of publication has also been confirmed, namely on the seventh day after the registration is confirmed. Confirmation of the issuance of this certificate of mortgage is delivered through the applicant's electronic domicile (e-mail). This HT-e service does not only serve for registration of mortgage rights. Transfer of mortgage rights, change of creditor names, and removal of mortgage rights (roya), can also be served through this system. This of course will make it easier for the community, adjusting to the conditions of the times with digital developments. In addition, this online pattern will minimize the interaction between service users and officers in the land office, which will certainly reduce corrupt practices that previously many people have complained about.

\section{Method}

The method is a method used in a study to achieve a goal, the level of accuracy, the number, and the type encountered, by classifying based on experience, it can be determined regularly and thought to achieve a goal. 5 The problems that have been formulated above will be answered or solved using normative legal research. According to Mukti Fajar and Yulianto Achmad stated that "Normative legal research includes research on legal principles, research on legal systematics, research on the level of legal synchronization, research on legal history and comparative legal research. Normative legal research or doctrinal legal research, namely legal research

5 Winarno Surakhmad. (2010). Pengantar Penelitian Ilmiah, Dasar, Metode dan Tehnik. (pp. 131). Bandung: Tarsito. 
that uses secondary data sources or data sources obtained through library materials. ${ }^{6}$ The nature of the research used in this research is descriptive qualitative research. The purpose of this research is to reveal events or facts during the research.

\section{Main Heading of the Analysis or Results}

3.1 Electronic Mortgage Registration Based on the Regulation of the Minister of Agrarian Affairs and Spatial Planning / National Land Agency

Efforts towards legal certainty on land are listed in the provisions of the articles governing land registration, in Article 19 UUPA is mentioned to ensure legal certainty of land rights, UUPA requires the government to conduct land registration throughout the Republic of Indonesia which is' Cadastral Rech "means that it aims to ensure legal certainty, by conducting land registration, then the parties concerned can easily know the legal status of the particular land they face, location, area and boundaries, who owns and burden -what load is attached to the ground. Article 1 paragraph paragraph (1) of Government Regulation Number 24 of 1997 on Land Registration, explains the meaning of land registration, namely: "A series of activities carried out by the Government continuously, continuously and regularly, including collection, processing, bookkeeping, and presentation and maintenance of physical data and juridical data in the form of maps and registers of land plots and apartment units, including the issuance of certificates of rights for land plots that already have rights and ownership of apartment units and certain rights which burdens him."

Physical data according to Article 1 point 6 of Government Regulation Number 24 of 1997 concerning Land Registration is a description of the location, boundaries and area of the registered flat and unit, including information regarding the existence of a building or part of the building on it. Meanwhile, juridical data according to Article 1 point 7 of Government Regulation Number 24 of 1997 concerning Land Registration is a description of the legal status of registered land parcels and apartment units, in which the rights holder and the rights of other parties and other burdens impose on them.

Based on the above definition of Government Regulation Number 24 of 1997 concerning Land Registration, land registration is a state task carried out by the Government for the benefit of the people in order to guarantee legal certainty in the land sector. With certainty of rights, at least it will be able to prevent land disputes. With a land certificate, it is clear that the land has been registered at the land registration office so that everyone can know that the land has an owner..

In Indonesia, there are no documents that explain the implementation of land registration before the Dutch colonial era. This is understood because the law

6 Mukti Fajar dan Yulianto Achmad. (2010). Dualisme Penelitian Hukum Normatif dan Empiris, (pp. 153). Yogyakarta: Pustaka Pelajar. 
in effect at that time was customary land law, an unwritten law and from the beginning it was in effect among the indigenous people of Indonesia before the arrival of the Portuguese, Dutch, British and so on. ${ }^{7}$

Land rights arising from the process of being continuously exercised by the community, then legalized by the village authorities or the Village Head with an acknowledgment without a letter, so that finally a ownership relationship is born that is recognized by the community in the area and legally belongs to someone and / or the community in the environment. these customs. These are later recognized as land rights that were born because of the provisions of customary law. According to the AP. Parlindungan, stated that "Even though there is a customary law system that regulates the granting of rights to land according to local customs, it has not found a correlation between the granting of rights according to customary law with the registration of these land rights" .8

The amendment of Government Regulation Number 10 of 1961 to Government Regulation Number 24 of 1997 makes the implementing regulations of the LoGA more perfect. This improvement includes various things that were not clear in the old regulation (Government Regulation Number 10 of 1961), including the definition of land registration itself, the principles and objectives of land registration, in addition to providing legal certainty as well as to collect and present complete information. regarding physical data and juridical data regarding parcels of land owned by the community.

\subsection{Definition of Mortgage Rights}

Prior to the issuance of Law Number 4 of 1996 concerning Mortgage Rights, laws and regulations governing the imposition of land rights are listed in Chapter 21 Book II of the Civil Code relating to Mortgages, and Credietverband in Staatblaad 1908-542, which have been amended by Staatblaad 1930-190. Both of these provisions are no longer valid, because they are no longer in accordance with the needs of the people in Indonesia. This inadequacy is due to the fact that in the old regulations the only objects for mortgages and credietverband were property rights, usufructuary rights, and building use rights.

The birth of the law on the rights of dependents due to the order in Article 51 of the UUPA. Article 51 of the UUPA reads "Dependent rights that can be imposed on property rights, business use rights, and building use rights in Article 25, Article 33, and Article 39 are regulated in law. However, in Article 57 of the UUPA, it is stated that as long as the law of the right of dependents has not been established, the provisions on mortgages as regulated in the Civil Code and Credietverband are used. Since the enactment of the Law of Dependents, the provisions in the Second Book of Chapter XXI Article 1162

7 Arie Sukanti Hutagalung. (2012). Hukum Pertanahan di Belanda dan Indonesia. (pp. 133). Denpasar: Pustaka Larasan.

8 A.P. Perlindungan. (1986). Pandangan Kondisi Pelaksanaan Undang-Undang Pokok Agraria. (pp. 15). Bandung: Alumni. 
to Article 1232 of the Civil Code on Mortgages on land and in Staatsblad Year 1908 number 542 on the provisions of Creditverband are declared no longer valid.

Dependent rights according to the provisions of Article 1 item 1 of Law Number 4 of 1996 on Dependents on Land and Things Related to Land, are: "Dependents on land and things related to land, hereinafter referred to as liability rights, is a security right imposed on the right to land as referred to in Law No. 5 of 1960 on the Basic Regulations of Agrarian Principles, with or without the following other objects that are one unit with the land, for the repayment of certain debts, which giving priority to certain creditors over other creditors.

From the formulation of Article 1 point 1 of Law Number 4 of 1996 concerning Mortgage Rights to Land and Objects Related to Land, it can be seen that basically a security right is a form of guarantee for debt repayment, with pre-emptive rights, with the object of guarantee in the form of Rights. Right to Land as regulated in Law Number 5 of 1960 concerning Basic Agrarian Principles.

Mortgage entitles the object of the Mortgage as a whole and every part of it. With the payment of a part of the debt that is guaranteed a security right does not mean that part of the object of the security rights burden is freed, but the security right still burdens all the objects of the mortgage for the remaining outstanding debt. Thus, the repayment of part of the debtor's debt does not result in the release of part of the object of the collateral right. According to the provisions of Article 2 paragraph (1) of the Mortgage Rights Law, it is explained that the mortgage right is non-shareable (ondeelbaarheid). This indivisible nature can be distorted as long as this has been agreed in advance in the Deed of Granting Mortgage Rights (APHT).

Granting of mortgage rights can be obtained by making a Deed of Providing Mortgage Rights (APHT) which is made by the Official for Making Land Deeds (PPAT) in accordance with the applicable regulations. In the Deed of Granting Mortgage Rights (APHT) there is an insurance clause which is the basis of the existence of an insurance agreement on the object of the mortgage right. The purpose of the insurance agreement is to avoid the possibility of damage or loss of goods pledged as collateral due to natural disasters or deliberate action on the part of the debtor. With the signing of the Deed of Granting Mortgage Rights (APHT) by both parties, the insurance clause contained in the Deed of Providing Mortgage Rights (APHT) is binding and has compelling power for the parties making it. After registering the Deed of Granting Mortgage Rights (APHT) to the local land office, the insurance clause has the power to bind a third party, in this case the insurer or the insurer previously appointed by the bank to enter into an insurance agreement on the object of the insurance right with the party. debtor. After having the legal force to bind and have the power to compel the makers, then an insurance agreement is carried out on the object of the mortgage right. 


\subsection{Electronic Mortgage Registration Process Based on Regulation of the Minister of Agrarian Affairs and Spatial Planning / National Land Agency (ATR/BPN) Number 5 of 2020}

The granting of rights to an application for land rights is not only by looking at the procedural point of view. An application process is not sufficient only to analyze whether the applicant meets the requirements, is physically examined, measured, the application for land rights has been announced, etc. which are procedural, but must also be reviewed from a legal perspective.

In the business world, the most common problems that arise are those of entrepreneurs who wish to be able to develop their business but are constrained by small capital. In general, many entrepreneurs are unable to fulfill all the capital required for their business activities by themselves. To meet the availability of capital, entrepreneurs need other parties, namely banking institutions or financing institutions, to provide capital loans through a credit agreement mechanism. When a bank enters into a credit agreement with a debtor, the bank should have secured the payment of its receivables by requiring the delivery of objects by the debtor customer to the bank.

Mortgage is a security right to land for the settlement of certain debts which give priority to certain creditors over other creditors. In a sense, if one day the debtor defaults, the creditor as the holder of the Mortgage has the right to sell the object of the Mortgage by means of a public auction. In essence, the Mortgage is a follow-up agreement (accessoir) in the main agreement, namely the agreement on accounts payable. Thus, the existence, transfer and write-off of Mortgage Rights depend on the debt that is guaranteed repayment. The imposition of a mortgage that is carried out must fulfill two stages of activity, namely the stage of granting Mortgage Rights by the PPAT (which contains compulsory substance and optional promises) which are preceded by a principal agreement, namely a debt agreement, and the registration stage of the Insurance Rights by The Land Office which marks the birth of the Mortgage Rights.

The granting of Dependents is preceded by a principal agreement, namely the receivables agreement.73 In Article 10 paragraph (2) of Law Number 4 of 1996 on Dependents' Rights, namely the Granting of Dependents is done by signing the Dependent Rights Deed by PPAT which must comply with the provisions Legislation in force and for the enforcement of a liability right have been regulated in Article 13 paragraph (1) of the Dependent Rights Law which states that the grant of Dependent Rights must be registered with the land office. From these two regulations, it is an absolute requirement for the creditor who in this case is the bank in providing credit to the debtor with a guarantee of liability, then the Deed of Assurance of Liability (APHT) must be made as a guarantee of debt repayment of the debtor later where the creditor in this case the bank have the right to prioritize (preferential) from other creditors.

If an object of guarantee whose Deed of Assignment of Liability Rights is registered late by PPAT, in accordance with the provisions of Article 13 
paragraph (2) of Law Number 4 of 1996, that APHT made by PPAT must be registered with the Land Office no later than 7 (seven) days work after the signing of the Deed of Assignment of Dependents, by sending the Deed of Assignment of Dependents along with other letters required for the registration process to the Land Office. So, how is the implementation of the registration of the Act in BPN whether it is still accepted or whether it makes the act fall and what are the efforts of BPN to address the PPAT violation of the APHT registration deadline.

\subsection{Implementation Obstacles for Ppat in Performing Electronic Liability Rights Registration}

There are different views in analyzing an electronic document if it is linked to an authentic deed, that an authentic deed is a deed made by or in front of the competent official for it, according to the form and statutory rules in which the deed was made. Authentic deeds as formal evidence have perfect evidentiary power. With the very rapid development of information technology and is accommodated by the provisions of the Regulation of the Minister of Agrarian Affairs and Spatial Planning / Head of the National Land Agency of the Republic of Indonesia Number 5 of 2020 concerning Electronically Integrated Mortgage Services, there is discourse and thought to combine advances in information technology with the registration process. mortgage online.

Not long ago the Minister of Agrarian and Spatial Planning / Head of the National Land Agency (BPN) issued a Regulation of the Minister of Agrarian and Spatial Planning Head of the National Land Agency Regulation of the Minister of Agrarian and Spatial Planning / Head of the National Land Agency of the Republic of Indonesia Number 5 of 2020 concerning Integrated Mortgage Services Electronics which came into effect since it was promulgated, namely on April 8, 2020. The Ministerial Regulation is a continuation of the Regulation of the Minister of Agrarian and Spatial Planning Head of the National Land Agency Regulation of the Minister of Agrarian Affairs and Spatial Planning / Head of the National Land Agency of the Republic of Indonesia Number 9 of 2019 concerning Services Electronically Integrated Mortgage Rights. ${ }^{9}$

The issuance of this Ministerial Regulation is a step forward for the Ministry of Agrarian Affairs and Spatial Planning / National Land Agency in making it easier for people to get services from the ministry by taking advantage of technological developments. Although the Regulation of the Minister (Permen) of Agrarian and Spatial Planning (ATR) / Head of the National Land Agency (BPN) of the Republic of Indonesia Number 5 of 2020 concerning Electronically Integrated Mortgage Services has been issued and has been in effect since it was promulgated on April 6, 2020, but the implementation in the field related to the Regulation of the Minister of Agrarian and Spatial Planning / Head of the National Land Agency of the

9 Hasil Wawancara dengan Subandi, Pejabat Pembuat Akta Tanah (PPAT) Deli Serdang, tanggal 22 September 2020. 
Republic of Indonesia, it still depends on the readiness of each land office in implementing electronic systems in providing services to the community. ${ }^{10}$

The electronic mortgage service process has actually been started since the enactment of Permen ATR / BPN Number 7 of 2019 concerning the second amendment to Permen ATR / BPN Number 3 of 1997 concerning Provisions for Implementing Government Regulation Number 24 of 1997, as well as Minister of ATR Number 9 of 2019 concerning Services Electronically Integrated Mortgage Rights. That which is meant, among other things, regulates the PPAT Deed submitted to the Land Office which can be in the form of Electronic documents carried out through an electronic system. ${ }^{11}$

\section{Conclusion}

The HT-el registration process is based on Article 9 of the Regulation of the Minister of Agrarian and Spatial Planning / National Land Agency (ATR / BPN) Number 5 of 20, where creditors apply for HT-el services through the HT-el system provided by the Ministry. Obstacles in registering HT-el, when after the APHT is signed, the parties are then registered via an electronic system, server disturbances often arise when PPAT uploads deed documents and others, even though PPAT only has 7 (seven) working days after the APHT is signed to immediately register in the system. From creditors, the problem that is often faced is because they have not been registered and have not been validated in the Electronic HT service system.

\section{Acknowledgements}

The online mortgage registration process can run optimally, it is hoped that the BPN will check the documents carefully and accurately before 7 (seven) working days after the documents are registered with BPN. The government should disseminate information to the public or the community so that the parties can find out about HT-el and do not experience difficulties in implementing HT-el in registering mortgage rights at the local land office..

\section{References}

Arie Sukanti Hutagalung. (2012). Hukum Pertanahan di Belanda dan Indonesia. Denpasar: Pustaka Larasan.

A.P. Perlindungan. (1986). Pandangan Kondisi Pelaksanaan Undang-Undang Pokok Agraria. Bandung: Alumni.

AP. Parlindungan. (2011). Komentar Undang-Undang Tentang Hak Tanggungan atas Tanah Beserta Benda-benda yang berkaitan dengan Tanah. Jakarta: Mandar Maju

10 Hasil Wawancara dengan Subandi, Pejabat Pembuat Akta Tanah (PPAT) Deli Serdang, tanggal 22 September 2020..

11 Hasil Wawancara dengan Subandi, Pejabat Pembuat Akta Tanah (PPAT) Deli Serdang, tanggal 22 September 2020. 
Budi Harsono. (2016). Hukum Agraria Indonesia: Sejarah Pembentukan UndangUndangPokok Agraria, Isi, dan Pelaksanaannya. Djambatan.

Mukti Fajar dan Yulianto Achmad. (2010). Dualisme Penelitian Hukum Normatif dan Empiris. Yogyakarta: Pustaka Pelajar.

Rachmadi Usman. (2018). Hukum Jaminan Keperdataan. Jakarta: Sinar Grafika.

Salim HS. (2017). Perkembangan Hukum Jaminan di Indonesia. Jakarta: Raja Grafindo Persada.

Winarno Surakhmad. (2010). Pengantar Penelitian Ilmiah, Dasar, Metode dan Tehnik. Bandung: Tarsito. 